\title{
WHOSE BACKGROUND? \\ COMMENTS ON A DISCOURSE-ANALYTIC RECONSTRUCTION OF THE WARSAW UPRISING
}

\author{
Jan Blommaert
}

\section{Introduction}

Dariusz Galasiński's paper on 'The making of history' (Pragmatics, this issue) is interesting and informative from a variety of perspectives. On the one hand, it is a fine piece of political discourse analysis, written by someone who has mastered the art admirably well. On the other hand, I believe the paper raises and illustrates some crucial problems in critical discourse analysis. ${ }^{1}$ I will discuss one central problem in this paper: that of 'background' (facts, information, context) in critical discourse analysis. I do this largely in support of Galasiński's ambition: to demonstrate that linguistic analysis is capable of revealing the assumptions behind linguistic choice. But as an footnote to Galasiński's position, I take it that this ambition could not be fully realized without taking into account the reflexive dimension of the endeavor. More specifically, we need to ask: how 'loaded' is critical discourse analysis as a set of linguistic choices in its own right? Which assumptions do we take on board when analyzing linguistic choices (texts)?

Before embarking on the discussion of the problematic nature of background information, I want to give some intertextual 'background' to the kind of critique I shall be formulating. A version of Galasiński's paper (exclusively dealing with Walęsa's speech) was presented during the Groningen workshop mentioned in footnote 1, alongside analyses of the other speeches given during the Commemoration event of the 50th anniversary of the Warsaw Uprising. The workshop was intended to present a discourse-analytical reconstruction of the Commemoration event, and all the participants were given a set of materials in view of preparations for the workshop. It now strikes me how similar the historical background information given by the workshop organizers is to the background Galasiński gives in section 1 of his paper. The workshop organizers sent us an extract of a book on Polish history (Dziewanowski 1977: 129-139), which articulated a version of history very close to the one adopted by Galasinski in his 'background' section. I will discuss Dziewanowski's text in section 3 of this paper in connection

1 This paper is part of a larger discussion paper, presented at a workshop on the 50th anniversary of the Warsaw Uprising during the conference 'Frame and perspective in Discourse' (University of Groningen, November 1996), organized by Titus Ensink and Christoph Sauer. I am indebted to the participants of the workshop and especially to Dariusz Galasiński and Klaus Steinke for important comments on the original version of the paper. 
with Galasiński’s version.

\section{Problems with background}

I find the notion of 'background' increasingly problematic in assessing what we do as (critical) discourse analysts. In my view, a particular use of 'background data', 'basic facts', or 'some preliminary observations', hides a number of major methodological problems. Of course, these problems are not new. Situated discourse, as used for instance in anthropological linguistics or discourse analysis of 'real' texts/discourses, always involves a degree of definition, in which an unproblematized (and unanalyzed) set of 'facts' is given as setting the scene against which the texts/discourses will appear as meaningful communicative acts or events. Providing 'background facts' is clearly a matter of framing and perspectivizing: the background facts provide some knowledge necessary to understand the text/discourse itself, and elements of text/discourse meaning are contextualized by these background facts. ${ }^{2}$

More and more, however, I experience this routine (and undoubtedly necessary) practice as either paradoxical or at least partly inconsistent with our own analytical ambitions. Especially in critical discourse analysis, where scholars set out to unravel and expose ideological features of discourse and communicative practice, the incorporation of 'background facts' risks drawing in a series of unquestioned, ideologically neutralized assumptions about the nature, status and meaning of the analytical object, the text/discourse itself. In other words: the critical analysis of a text/discourse risks being undermined (and ideologically plied) by the uncritical acceptance of 'established' background facts related to the text/discourse. Our critical orientation thus becomes partial and methodologically questionable, because we exclude from critical analysis the frame and perspective in which we place our object. We consequently grant these texts an authority which, from a critical discourse analysis point of view, they should not be given a priori.

Often, this practice of using background facts in a neutralizing and analytically unproblematized fashion has a dimension of interdisciplinarity. The facts we cite as background to the text/discourse are handed to us by other sciences -anthropology, sociology, history, descriptive linguistics. They may include statements about cultural practices, social relations, historical events, linguistic structures, which then serve to explain aspects of when, how, why the text/discourse was produced. The statements are, however, rarely taken as a target of analysis in their own right; they are generally taken at face value, as 'facts' in the commonsense meaning of the term: things we know, about which we should no longer worry and which we should not question, investigate or deconstruct. We thus neutralize the socially-constructed nature of scholarly practices and results from other sciences, while being highly critical and unassuming with regard to our own results. We do not contextualize the

${ }^{2}$ In a particular way often stipulated by discourse analysts: context helps us to read texts; what is in the texts becomes more transparent or meaningful by referring to context. That this assumed pattern is not without problems should be clear from the discussions presented in Auer \& Di Luzio (eds. 1992) and Duranti \& Goodwin (eds. 1992). See also Bauman \& Briggs (1990) for insightful comments. 
'facts' we use to contextualize our own object, and so avoid or overlook a quite relevant question: when giving 'background' to our data, whose background are we giving? Who produced these facts, when, how, why?

\section{The historical account}

Let us now take a look at the background offered by Galasiński. Galasiński spends four paragraphs discussing the background. In the first paragraph, the Uprising is chronologically and politically situated. Galasiński stresses the intention of the Home Army to demonstrate their prowess and importance and, in the same move, to preempt the Soviet invasion of the city, which would have involved the establishment of a Communist regime. The second paragraph delves somewhat deeper into the military dimensions of the Uprising, emphasizing the role of the Red Army as a potential ally who by its (politically inspired) inertia became a betrayer. Against the hopes of the Home Army, the Soviets "stopped" at the Vistula, and "looked on as Warsaw was gradually being destroyed". Stalin also acted uncooperatively by refusing the Allies to use Soviet-controlled air bases. The third paragraph stresses the historical importance of the Uprising as "one of the most remembered and cherished Polish military operations of the Second World War". This importance is said to have been underscored by the Communists' postwar downplaying of the Uprising as an important event, since that would have highlighted the negative historical role of the Soviets. The final paragraph connects the events of 1944 to the Commemoration event of 1994, stressing the controversial character of inviting the German and Soviet authorities. The whole 'background' section is written in declarative sentences and is presented as a factual historical account. ${ }^{3}$ The declarative, matter-of-fact style is arguably an instance of 'politics of representation', of "competition over the meaning of ambiguous events, people, and objects in the world" (Mehan 1996: 253), in which Galasiński metapragmatically marks the information he provides as (clear unambiguous) facts, in other words, as an authoritative version of reality. Arguments for this claim will be given throughout the rest of the paper, but the point is this: Galasiński presents as 'background facts' (with all the above-mentioned connotations of the term) what is essentially a highly controversial, ambiguous and obscure (i.e. 'unknown') historical episode. Similar and more extensive instances of this move could be found in Dziewanowski's text, which served as the 'background information' for the Groningen workshop.

The extract from Dziewanowski (1977) provided us with an authoritative historical account of the Warsaw Uprising. It was taken from the kind of historical book that would be perceived by many among us as a standard reference work: a book on Polish history in the twentieth century (i.e. written by someone who utilized a wider than purely local perspective on the Warsaw Uprising), published by a Polish scholar (i.e. involving assumptions about access to Polish-language sources

${ }^{3}$ In the abstract originally accompanying Galasiński's manuscript, the factual metapragmatic qualification was made explicit: "Of particular interest is the manner in which the speeches handle the fact that the Soviet Army did not prevent the deaths of more than 200,000 inhabitants of Warsaw $[\ldots] "$. 
and eyewitness accounts, as well as a degree of general credibility), and published by a prominent Western academic publisher, undoubtedly after detailed refereeing by other acknowledged specialists. The work is also rather old (it was published in 1977), which grants some prima facie credibility to the book. The use of this text now, almost twenty years after its appearance, would suggest that it is still a standard account of Polish history, unmatched by other, more recent works. This is how I, at first, received and perceived this document. I read the colophon, decided that it was 'good', then read the whole text and found it instructive and balanced.

The story sketched by Dziewanowski focuses (i) on the optimistic perception of the Soviet offensive among the Polish underground (the Soviets were irresistibly moving towards Warsaw, while the German defence was becoming weak), (ii) on the political dimension of the decision to unleash the Uprising (the struggle for supremacy by the London government, against the Communists), (iii) the unexpected halt of the Soviet offensive, jeopardizing the success of the Uprising, combined with the refusal of help to the insurgents by the Soviets suggesting a deliberate move to let the pro-London forces bleed to death, and (iv) on the altogether cynical attitude of Stalin towards the Uprising, and the fact that the Soviet inactivity was inspired by political rather than by military motives.

Looking closer at the text, two things can be noticed. First, it looks as if all the moves and messages of the Soviets were ambiguous and allowed interpretations of encouragement to organize the Uprising - and in hindsight, as encouragements to commit suicide. There is an overdose of modal qualifications when the information about Soviet actions and intentions prior to the Uprising is discussed. The Red Army's offensive "appeared irresistible"; the Germans "showed signs of exhaustion and demoralization"; to the insurgents, "it seemed that the Wehrmacht would be unable to offer resistance along the Vistula line"; a Soviet radio appeal to the Polish people "apparently indicated that the Soviet command was about to launch an assault on Warsaw", hence the leader of the underground "judged the situation ripe for the uprising to begin". The Polish resistance makes a string of interpretations of Soviet actions, and uses them as the basis for planning the precise date of an offensive in Warsaw. This complex calculation would involve estimates of the speed and scale of the Soviet offensive and undoubtedly a few other technical issues - a series of impressions and appearances would hardly vindicate the decision, it seems in hindsight. All the perceptions of the Soviet moves are clearly marked as conjectural in the historical account: these may have been the meanings of Soviet moves and messages, but they might as well have been different. Nevertheless, these conjectures are plausible for the historian. Dziewanowski interprets the Soviet communiqué saying that Marshal Rokossovsky's armies "were advancing on Warsaw" as an unambiguous announcement that the troops "had been about to capture Poland's capital", thus sanctioning the Home Army's estimate of the timing for the Uprising as legitimate.

The second remarkable point was the author's selective quoting. As a matter of routine, I always take note of who is cited and how when reading politically sensitive texts. In this case, Dziewanowski quotes the comments of (i) Arthur BlissLane, US Ambassador to Poland, (ii) Eisenhower (quoted by Bliss-Lane), (iii) General Bor-Komorowski, (iv) an unidentified "Communist member of the new Polish government" mediated through Bliss-Lane's words, (v) George F. Kennan and (vi) Jan Ciechanowski, "a Western-oriented Polish historian" who revised the 
standard account of the Uprising. The statement made by the Communist member of the new government (narrated by Bliss-Lane) corroborates the thesis that political rather than military considerations guided the Soviet actions during the Uprising. They corroborated, in other words, the post-war anti-communist version of the story. Similarly, Ciechanowski's amendment to the dominant historical account in which both Nazis and Soviets were held responsible for the débacle of the Uprising is accepted, but serves as the starting point for a new line of argument in which the Soviet actions are seen as foreshadowing an inevitable geopolitical reshuffling of postwar Europe. The failure of the Uprising was a consequence of the Polish government's misjudgment of international support, the Soviets having bargained beforehand that Poland would become part of their sphere of influence. Still, the agreement of Yalta had to be implemented, and so the Soviets decided to let the Polish Home Army be slaughtered by the Nazis -- a paraphrase of George Kennan's statement. The "middle position", taken by the Polish historian, in Dziewanowski's eyes does not take away the burden of guilt from the Soviets; it merely reformulates the nature of the guilty behavior.

Dziewanowski mentions the fact that the Warsaw Uprising gave rise to bitter controversies in which Communist historians were pitted against non-Communist historians. The Communist account is not mentioned. Dziewanowski refers to the works of a Polish historian, Zenon Kliszko, who is qualified as "Gomulka's friend". This is an interesting point, for it indicates how Dziewanowski perceives Communist history as biased (the historians are friends of the Communist leaders), while people such as Bor-Komorowski, Bliss-Lane, Eisenhower, Kennan or (when it comes to the Friendship Treaty) Brzezinski are treated as historical sources with some authority. He calls their camp of historiography the non-Communist camp, rather than the anti-Communist camp. We know that they are not Communists, but what are they? Surely, Eisenhower, Kennan and Brzezinski, let alone Bor-Komorowski or BlissLane cannot be treated as ideologically neutral actors in the story and its narrative history? Is the non-/anti-Communist version of a controversial historical issue the undisputed version? Then why is it controversial?

The point we have to take on board before we move any further is that the 'historical background' offered in Galasiński's paper as well as in the Dziewanowski text is a particular historical account, in itself worthy of deconstruction and critical analysis. It is not something we can simply base ourselves upon in analyzing texts commemorating the Uprising and hence crucially hinging on representations of history. Galasiński's and Dziewanowski's account of the Uprising are perfectly in line with the historical representation of the Uprising articulated in the various speeches, because it is the anti-Communist account. The point is, however, that this is brought into the discourse analysis as a form of entextualization (Bauman \& Briggs 1990; Silverstein \& Urban 1996): it provides us with a preferred metadiscourse on the various speeches we are supposed to analyse. It is, in itself, an unintended but quite common case of framing and perspectivizing discourse analysis, a case of suggesting an 'obvious', unquestioned and unquestionable background reading to the texts. Note also that, from a critical perspective, $a$ preferred metadiscourse is always someone's metadiscourse. Whose voice produces the metadiscourse attaching authority to one version of history? Certainly not that of the Soviets, as will become clear in the next section. 


\section{The absent voice}

We have to delve somewhat deeper into the issue of background facts. I hope to have argued clearly so far that the entextualization suggested in the background facts represents - broadly speaking - an anti-Communist account of the Warsaw Uprising. The background given by Galasiński in order to provide us with some knowledge of what happened in 1944, represents one side in the historical controversy. Its sympathy lies clearly with the Home Army (despite its admitted naivity and its errors of judgment). The author is, however, adamant with respect to the Soviets' role as betrayer guided by political strategies rather than by military ones.

When we look at the various speeches of the Commemoration, we see that the roles sketched by Galasiński and Dziewanowski are all to various degrees incorporated in the speakers' views, including those of the Russians. The Russian representative Filatov is somewhat circumspect with regard to the issue, and calls for historical investigation. At the same time, however, he refers to "old-time mistakes" and "ignominious blunders" in a way which is hard to detach from the particular occasion and topic of the speech. Does this mean that the Soviets are acknowledging their unfortunate role of betrayer?

It has become a common trope to equate (post-1990) "Russians" with (pre1990 ) "Soviets", especially when historical periods such as the Second World War are concerned. The simple fact, however, is that today's Russians are not yesterday's Soviets, just as today's Germans are not yesterday's Nazis. In fact, of all the parties involved in the Warsaw Uprising, two are not represented during the Commemoration: the Nazis (the "perpetrators") and the Soviets (the "betrayers"). In the case of the Nazis, historical logic is respected: the original perpetrators are still presented as perpetrators; in the case of the Soviets, however, a historical rolereversal is performed, and from allies they have become 'betrayers'. Furthermore (but related to this role reversal), whereas the German President only has to acknowledge guilt for one crime -- the crushing of the Uprising itself -- the Russians have to acknowledge guilt both for their betrayal during the Uprising and for the post-war imperial oppression of Poland. The link between both historical events, the Uprising and the Communist rule, is constantly made during the Commemoration, and speakers celebrate both the heroism of 1944 and the collapse of Communism in 1990.

This trope has to be questioned. First, equating 'Russians' with 'Soviets' reduces a multi-ethnic complex system to one ethnicity. ${ }^{4}$ Stalin, to my recollection, was a Georgian and not a Russian. It is also plausible that Zhukov's troops were made up not only of Russians, but also counted Byelorussians, Lithuanians, Kazakhs, Georgians, Ukrainians and so on. Where are they? And can the Russian representative (though himself to some extent usurpating the legacy of Soviet superpower status) be called upon to account for Soviet actions of the past? Is the ethnicization of the Soviet not a first step in the reinterpretation of history (as it is

4 This is an emblematic move ideologizing the historical perception of the Soviet Union as dominated by ethnic Russians, thus suggesting a (popular) line of explanations for the fall of the Soviet empire as the result of oppressed ethnicities. See Blommaert \& Verschueren (1996). 
e.g. in the Baltic States or in other newly independent ex-Soviet republics)? This is connected to the second question. Is the link between 1944 and 1990 not already based on a rewriting of history, in which 'Russians' signify the liberated Soviet people? Could it be possible that the Warsaw Uprising becomes such a big historical event, not because it possessed an 'intrinsic' historical importance suppressed by the Polish Communist regime (as Galasiński believes), but precisely because it can be inserted seamlessly as a trope or an exemplum in a contemporary discourse of postcommunism and legitimized anticommunism? It could certainly motivate an allignment of discourse participants, in which the Russian representative can afford to dismiss responsibility for the Soviet actions, because he embodies postcommunism. In that sense, and contrary to what Galasiński suggests, Filatov's reference to the need for historiography would not be so much an attempt to dodge difficult questions, but rather an expression of the new postcommunist relations between his country, Poland and the former Allies, guided by the spirit of rationality, objectivity and honesty (here all seen in contrast to - Soviet - 'ideology').

As for the events of 1944, the absence of a Soviet voice is remarkable, the more since the issue of guilt and responsibility with regard to the Uprising is consistently referred to as controversial and unclear. The reason for this absence cannot be the lack of available historical material. I myself have bought quite a few books published by Soviet publishers, and at least two of them contain autobiographical accounts of the Warsaw Uprising. Needless to say, they provide a quite different account of the events. I shall quote and discuss these two sources at some length.

The first Soviet account I found in the memoirs of Marshal Georgi Zhukov, the commander of the Red Army in charge of the operations on the Western front (Zhukov 1974). Throughout these amazingly informative memoirs, great emphasis is put on the frailty of the Soviet offensives. Nowhere do we meet the image (so widespread elsewhere, and also present in Dziewanowski's account) of an irresistible steamroller, crushing all German opposition once it got moving. On the contrary, Zhukov consistently emphasizes the precariousness of the operations, the difficulties encountered in preparing massive offensives, the immense losses and above all, the fierce opposition of German troops. ${ }^{5}$ In Zhukov's account, whenever the Red Army stops, it is because of military-technical reasons. Let us now take a look at the passage in his memoirs in which he discusses the operations in the Warsaw theatre in 1944 (Zhukov 1974: 301ff.). Zhukov is very brief with regard to the Uprising itself. I shall quote his words in full:

"As was established later, neither the command of the Front nor that of Poland's 1st Army had been informed in advance by Bor-Komorowski, the leader of the uprising, about the forthcoming events in Warsaw. Nor did he make any attempt to coordinate the insurgents' actions with those of the 1st Byelorrussian Front [i.e. the Red Army Front closest to Warsaw]. The Soviet Command learned about the uprising after the event from local residents who had crossed the Vistula. The Stavka [=coordinated high command] had not been informed in advance either.

${ }^{5}$ Thus, Zhukov repeatedly notes the fact that German crack SS troops were transferred to the Eastern front after D-Day. The war on the Eastern front, as Zhukov lived it, was not a walk-over from Stalingrad to Berlin. It was bloody hard work. 
On instructions of the Supreme Commander [= Stalin], two paratroop officers were sent to Bor-Komorowski for liaison and coordination of actions. However, Bor-Komorowski refused to receive the officers.

To assist the Warsaw insurgents, Soviet and Polish troops crossed the Vistula and seized a section of the Warsaw Embankment. However, Bor-Komorowski again made no attempt to make any reciprocal move in our direction. In a day or so the Germans brought up considerable forces to the Embankment and began pressing our troops. A serious situation developed, and our troops suffered heavy losses. Having considered the situation, and being convinced of theimpossibility of capturing Warsaw, the command of the Front decided to withdraw the troops from the Embankment to its bank."

Zhukov thus emphasizes Bor-Komorowski's unwillingness to accept coordinated actions, the military efforts that were made by the Red Army (including airdroppings of food, ammunition and medicines) and the practical impossibility to capture Warsaw at that particular time. The Warsaw Uprising did not fit into the Soviet strategic tempo, and militarily it was doomed to failure.

These notes are fully coherent with Zhukov's detailed description of all the operations in the direction of Berlin. All operations are carefully planned, and very little room is left for improvisation or revision of plans once they have been drafted -- hence, Bor-Komorowski's failure to coordinate efforts with Rokossovsky was not purely a matter of procedure, but was an essential condition for being able to support the Uprising. Zhukov emerges as a technocrat who thinks in purely operational terms. Thus, when discussing the halt of the troops in the ModlinWarsaw sector, Zhukov advocates a move to defensive positions, given the degree of exhaustion of the troops. When asked by Stalin whether a continued offensive in the Modlin-Warsaw area would be feasible, he answers:

"My opinion is that this offensive will yield us nothing but casualties (...) From the operational viewpoint, we don't particularly need the area north-west of Warsaw. The city must be taken by skirting it on the south-west, and at the same time dealing a powerful splitting blow in the general direction of Lodz-Poznan."

This probably meant the death warrant for the Warsaw insurgents. The fact is, however, that Zhukov uses exclusively military arguments for his decision. The image of the Red Army, sitting idle in waiting on the banks of the Vistula, complacently watching the Nazis slaughter the Warsaw people, is far away. Zhukov was particularly wary of crossing the Vistula, fearing that the Germans might put up heavy defenses and inflict terrible losses on the Red Army. In all his moves during the offensives since Stalingrad, such operations are consistently dealt with in a very careful way, Zhukov being particularly apprehensive about exposing flanks of his Army to enemy counter-attacks. The same goes for capturing major cities. Always there is a period of halt and preparation prior to taking a city. So when the Red Army stopped in front of Warsaw, it just might have been a matter of military logic. This, at least, is the opinion of the Soviet commander.

The second Soviet source are the memoirs of a diplomat, Valentin Berezhkov (Berezhkov 1982), an aide to the Soviet Minister of Foreign Affairs Molotov. Berezhkov took part in all the major diplomatic events of World War II, including the Soviet-German Pact of 1939 and the conferences of Teheran, Yalta and Potsdam. He spends a whole section discussing the Warsaw Uprising (Berezhkov 1982: 356-365), recognizing that it was an event of major significance in the 
diplomatic affairs surrounding World War II.

Berezhkov's account is much more political than Zhukov's, and his narrative is more than Zhukov's littered with Soviet jargon ('reactionaries', 'revolutionaries', 'bourgeois' etc.). At the same time, he provides us with an image of at least shared guilt. He stresses the fact that Poland had been assigned to the Soviet sphere of influence during the Teheran Conference, and that, consequently, Roosevelt also contributed to the undermining of the Polish government in London. Thus, when the US Ambassador to London, Harriman, visits Roosevelt and informs him of the fact that Churchill changed his mind on the Polish question, Roosevelt merely

"repeated to Harriman his previous position, the essence of which was that the Polish émigré government must be reorganized so as to bring about conditions favourable to lasting friendship between Poland and the Soviet Union."

The discussions between the Polish emigré leader Mikolajczik and the Soviet diplomat Lebediev, granted great importance in Dziewanowski's account, are nowhere mentioned in Berezhkov's account. What emerges is a picture in which the Soviet government consistently sticks to the terms of the Teheran agreements, supported by repeated confirmations of these terms by Roosevelt. So there were, in Berezhkov's account, no ambiguous messages given by the Soviets. The Soviets emphasized the need to reach an agreement between the London émigré government and the Polish Communist government, and they saw the latter as the most representative body, "best informed about conditions in Poland".

What then about the Uprising? Berezhkov shetches a picture in which the Polish émigré authorities attempted to boycott the effectiveness of the activities of the Communist government, thus trying to create a fait accompli in which their organization could claim representativeness of the Polish people. Realizing that this strategy would clash with Moscow's and Washington's decisions about the future of Poland, they "hastily took a number of countermeasures, chief among which was organising the Warsaw uprising", which coincided with Mikolajczyk's visit to Moscow. "Reactionary groups in Poland hoped that the uprising in Warsaw would strengthen Mikolajczyk's position at the Moscow talks".

As soon as the Soviets were informed about the Uprising, they made it clear that it was doomed to failure. Stalin himself told this to Mikolajczyk, and a Soviet communiqué to the British Government of August 16 reaffirmed it. Berezhkov also elaborates on the military impossibility of supporting the Uprising in a way which fully corroborates Zhukov's version. The 1st Byelorussian Front was exhausted after a 40-day offensive, and the Germans had put up new and stronger reinforcements. Despite that, units were sent to assist Bor-Komorowski and material was dropped from the air. Also, part of the failure was due to the Polish command's refusal to coordinate actions with the Soviet units. The Soviet units suffered heavy losses and withdrew, while air support continued until the capitulation of the Home Army.

Berezhkov calls the Uprising an "unconscionable gamble of the émigré government", adding that "[o]n the one hand, the Warsaw uprising demonstrated the selflessness and heroism of the rebels in the struggle against the occupying forces; on the other, it was a criminal act of an anti-Soviet policy pursued by the government of Mikolajczyk and those leaders of the London émigré government who were in Poland". In other words, contrary to Dziewanowski's thesis that the 
Soviet actions were inspired by political motives, Berezhkov suggests that the Polish actions were inspired by political rather than by military motives.

These two Soviet sources present us with a perspective which is radically different from that presented in the 'background facts' offered by Galasiński and Dziewanowski. Of course, one can object that these two sources are biased, or 'propaganda'. But this then begs the question as to why and by what standards one would call Kennan, Eisenhower, Brzezinski and others 'unbiased', or, why our version would be a case of 'information', and theirs of 'propaganda'? The question is therefore not which perspective is true and which is false. It is rather: whose perspective did we adopt and grant authority when we accepted one version of history as the background facts necessary to know what the speeches talk about? The question is relevant, for we now know that there are different perspectives, each of which should be tested as to its historical accuracy.

\section{The background of postcommunism}

I would venture that the background given by Galasiński and by Dziewanowski is that of the postcommunist 'new order'. The version of history in which the Soviet voice is all but eliminated characterizes the political-ideological environment in which we now proceed to critically analyze discourse produced on a historical topic. It has become the default way in which we now entextualize these speeches, and the reasons for which we entextualize them in this particular way are often unquestioned. We do it because of political commonsense, ethical awareness, ideological conviction, and a load of other reasons commonly seen as 'unscientific'. Commonsense, as we all know, is the locus of mainstream ideology, and incorporating commonsense assumptions into our own scholarly discourse is a way of ideologizing it. We analyze the speeches of the Commemoration in a way which has taken on board all the assumptions, all the acquired historical 'truths' which are articulated in the speeches and which serve as a point of departure for the various speakers to develop particular details of their historical contribution to the Uprising. In this way, we can dive into the text/discourse, and be critical within the confines of the text/discourse. What is outside the text/discourse, what the text/discourse is based on, is 'known'.

Our professional vision as critical discourse analysts consists not only of "[d]iscursive practices (...) used by members of a profession to shape events in the domains subject to their professional scrutiny" (Goodwin 1994: 606), but also and simultaneously of elisions of potentially explosive questions that surround texts/discourses. We assume, within our small professional community, a great deal of political, social, cultural and ethical wisdom, which we can then keep outside our analytical practice. We can simply assume that all our colleagues share the same assumptions about facts of politics, society and so on. For instance, critical discourse analysts are typically 'leftists', liberals -- at least, I haven't met a right-wing critical discourse analyst yet. Is this trivial? I don't think so. It may prove to be the methodological Achilles' heel of the discipline, because it frames what we are doing in ways that are hard to motivate, given our stated ambition to demonstrate connections between discourse and social power structures or ideologies. 


\section{Conclusions: Quid background?}

But what to do with this 'background', this necessary evil we need in order to give grounding to the texts/discourses we intend to analyze? Here, we touch upon a problem of the definition of our object, in other words on a central methodological question of which we should be aware and which we should not avoid.

There is a tendency to restrict 'data' in critical discourse analysis (but also on a more general level of pragmatics and sociolinguistics) to linguistically identifiable data. Texts/discourses are prototypically chosen on the basis of formal-linguistic criteria: they need to be products of language. And at this point, many of us take a linguistic turn. Language is still to various degrees the autonomous object defined by Saussure and conflated by some of his followers so as to make some contextual elements collapse into language. Language, to linguists, never collapses into something else. They may claim it does, but in actual practice the relationship is the other way round. Dell Hymes' old observation, that "[l]inguistics, the discipline central to the study of speech, has been occupied almost wholly with developing analysis of language as a referential code" (1974: 32) by and large still holds. Galasiński's assumption in section 2 of his paper, "along the lines of critical language study [...] that linguistic analysis is capable of revealing the assumptions behind linguistic choices" (specifying further that this should include an analysis of the syntactic and lexico-grammatical levels of a text), reveals more than just an analytical preference. It reveals an adherence to traditional concepts of text and linguistic structure which cannot be undone by claims to the contrary. In Galasiński's analysis of Walęsa's and Filatov's speeches, processes of intertextuality, dialogism, textualization and so on are stopped and reduced to one textual event (in itself reduced to one textual object) which is then supposed to tell the whole (political, historical, cultural, ideological) story. This story is made explicit in section 5 of his paper, where he provides again some 'background', illuminating, it seems, some of the intertextuality, the motives for particular linguistic choices, and the wider historical framing of Walęsa's and Filatov's speeches. But just like in the introductory background section, the information provided here is disconnected from the textual evidence offered in the analysis. It is not in the text, and neither is the object-text really made part of the wider perspective offered in section 5 . The introductory background, the linguistic text-analysis, and the wider background in section 5, are three juxtaposed narratives said to be connected in the sense that the two 'contextual' narratives explain - semantically - the object text.

The issue is a fundamental one, and it is rooted in traditions of constructing the object of inquiry that are hard to get rid off. We need to explore other dimensions of textuality than the ones we are used to dealing with. The question of interdisciplinarity is implicit in my critique, though it needs to be formulated in a specific way. I tend to agree with Dell Hymes' call for a revision of the scope of various disciplines, by redefining the object of inquiry (cf. Hymes 1974: 32). Interdisciplinarity, in other words, at the level of what we are analyzing, rather than 
at the level of how we analyze. ${ }^{6}$ My comments in the previous sections were aimed at demonstrating that the scope of our critical inquiry is drastically reduced when we cut off the 'background facts' from the texts, and refuse to see the background as a form of entextualization in its own right. The object which I advocate is partly text in the traditional sense of the term, and partly 'non-text'. Both are part of a process of textualization, of 'doing text', of 'texting'. And a critical analysis of this object should, for instance, also inquire into the reasons why we look at particular texts in particular ways at this particular time in history, into what we bring along into our analysis in terms of assumptions, images, attributions and so on.

Does this solve our problems? Not completely, of course. But it allows us at least to distinguish between the various perspectives we apply - as a matter of normalcy and embedded in an ideology of our own professional practice - to our 'data'. It should be clear that we very often 'jump', not necessarily to conclusions, but certainly to implicit acceptations of motives for doing things in a particular way, motives which need to be called into question every now and then as a matter of critical reflection on our own practice. For instance, analysts often 'step out' of the object-text/discourse in order to explain why a text/discourse is political or ideological. Texts/discourses are then defined as political or ideological by associating them with an apparently objectively existing sphere of 'political' or 'ideological' practices, structures or institutions (e.g. the common simplism that political discourse is discourse produced by politicians). In this way, rather than to call into question the social order in which discourse appears and functions, we adopt the basic structure of this social order and integrate it into our way of viewing our object.

I pray Galasiński and all those who might identify with him as the objects of my critique to view the comments made here as friendly and constructive. I believe we need to reinvestigate our joint claims about the deep embeddedness of language in social life, time and culture, and turn it into more than just a taken-for-granted truth which allows us to proceed with linguistic business as usual. When these claims are taken seriously - and again I have to paraphrase Hymes - texts, contexts, linguistic structures and ultimately linguistics will never be the same again.

\section{References}

Auer, Peter \& Aldo Di Luzio (eds.) (1992) The contextualization of language. Amsterdam/Philadelphia: John Benjamins Publishing Company.

Bauman, Richard \& Charles Briggs (1990) Poetics and performance as critical perspectives on

\footnotetext{
${ }^{6}$ Hymes' appeals to a revision of the scope of the various disciplines involved with discourse and speech appear in various places in his oeuvre, but have remained largely unnoticed. The essence of his stance is that sociolinguistics should not become a new 'discipline' like linguistics or anthropology; rather it should be an interdisciplinary influence on both (and other) disciplines, and the effect of sociolinguistics should be that linguistics and anthropology would be changed. Linguistics would have adopted the social dimension of language as part of its object, and anthropology would have adopted the importance of discourse and its social embeddedness as part of its object. See Hymes (1971) for a particularly detailed argument.
} 
language and social life. Annual Review of Anthropology 19: 59-88.

Berezhkov, Valentin (1982) History in the making: Memoirs of World War II diplomacy. Moscow: Progress.

Blommaert, Jan \& Jef Verschueren (1996) European concepts of nation-building. In Edwin Wilmsen \& Patrick McAllister (eds.), The politics of difference: Ethnic premises in a world of power. Chicago: University of Chicago Press, pp. 104-123.

Duranti, Alessandro \& Charles Goodwin (eds.) (1992) Rethinking context. Cambridge: Cambridge University Press.

Dziewanowski, M.K. (1977) Poland in the twentieth century. New York: Columbia University Press.

Goodwin, Charles (1994) Professional vision. American Anthropologist 96.3: 606-633.

Hymes, Dell (1971) Sociolinguistics and the ethnography of speaking. In Edwin Ardener (ed.), Social anthropology and language. London: Tavistock, pp. 47-93.

Hymes, Dell (1974) Foundations in sociolinguistics: An ethnographic approach. Philadelphia: University of Pennsylvania Press.

Mehan, Hugh (1996) The construction of an LD student: A case study in the politics of representation. In M. Silverstein \& G. Urban (eds.), Natural histories of discourse. Chicago: University of Chicago Press, pp. 253-276.

Silverstein, Michael \& Greg Urban (1996) The natural history of discourse. In M. Silverstein \& G. Urban (eds.), Natural histories of discourse. Chicago: University of Chicago Press, pp. 1-17.

Zhukov, Georgi (1974) Reminiscenses and reflections, vol. 2. Moscow: Progress. 